\title{
Correlation of mastering effective sentences and learning motivation to writing skills of explanation text for high school students
}

Yulia Pebriani ${ }^{\mathrm{a}, \mathrm{I}}$, Refa Lina Tiawati $\mathrm{R}^{\mathrm{b}, 2}$

${ }^{a, b}$ Education of Language and Literature Education STKIP PGRI West Sumatra Iyuliafebriani.yf@gmail.com ; ${ }^{2}$ refalina.2012@gmail.com

\begin{tabular}{ll}
\hline Article's information \\
\hline History: & $: 23$ Okotober 2020 \\
Submitted & $: 7$ April 202I \\
Revised & $: 30$ April 202I \\
Published &
\end{tabular}
ABSTRAK Artikel ini bertujuan untuk memaparkan dan mendeskripsikan mengenai hubungan penguasaan kalimat efektif dan motivasi belajar yang dimiliki siswa terhadap keterampilan menulis teks eksplanasi. Hasil pengolahan data dengan

Kata kunci: menggunakan regresi ganda terhadap variabel menulis teks eksplanasi (Y)

Effective sentences,

learning motivation, writing explanatory text mengahasilkan koefisien arah regresi ganda (b) sebesar 0,094 untuk penguasaan kalimat efektif (XI) dan 0,79I untuk motivasi belajar (X2) serta konstanta (a) sebesar 50,547. Dengan demikian, bentuk korelasi antara ketiga variabel tersebut dapat dinyatakan oleh persamaan regresi ganda $\dot{Y}=50,547+0,094$ XI $+0,79 \mathrm{I}$ $\mathrm{X} 2$. Hasil data yang diperoleh berupa korelasi yang memiliki nilai signifikan anatara penguasaan kalimat efektif dan motivasi belajar terhadap keterampilan menulis teks eksplanasi sebesar koefisien determinasi $\mathrm{R}^{2}=0,375$, penguasaan kalimat efektif dan motivasi belajar mempengaruhi keterampilan menulis teks eksplanasi sebesar 37,5\%.
Key word: Kalimat efektif, motivasi belajar, menulis teks eksplanasi

\begin{abstract}
This article aims to describe and describe the relationship between effective sentence mastery and student motivation to write explanatory text skills. The results of data processing using multiple regression to the explanatory text writing variable (Y) resulted in a multiple regression coefficient (b) of 0.094 for effective sentence mastery (XI) and 0.79 I for learning motivation (X2) and a constant (a) of 50.547. Thus, the form of the correlation between the three variables can be expressed by the multiple regression equation $\dot{Y}=50.547+0.094 \mathrm{XI}+0.79 \mathrm{I}$ $\mathrm{X} 2$. The results of the data obtained in the form of a correlation that has a significant value between effective sentence mastery and learning motivation on explanatory text writing skills at the coefficient of determination $\mathrm{R} 2=0.375$, effective sentence mastery and learning motivation affect explanatory text writing skills by $37.5 \%$.
\end{abstract}

Copyright (C) 2018 Universitas Ahmad Dahlan. All Right Reserved

\section{Introduction}

Language as a communication medium will only be useful if it is mastered by those who enter the communication circle. In other words, we are required to have a good insight into the Indonesian language so that we can produce grammatical sentences in communication, both spoken and written, and we can recognize whether the sentences produced by other people are grammatical or not. In spoken language, the sentences used should be effective so that they can be easily understood by the interlocutor. Effective sentences are sentences that have sharp and interesting expressiveness. Sharp means that the sentence is able to convey a concentrated meaning. Interesting means that the sentence is good, it touches the emotions of the reader or listener (Mulyono, 201 I: 33). Therefore, according to the author, effective sentences have sharp, emotional and communicative characteristics. Based on the meaning of the sentence above, the benefit of using effective sentences is to increase writing effectiveness.

In line with Emianna Tumanggor's (2016) opinion writing is one of the language skills that must be mastered, because through writing we can convey ideas, ideas or opinions. One of the skills studied was writing skills because this was starting to be ignored by students. Writing activities, the writer must be skilled in using grammar, sentence structure and vocabulary so that it can create a good and correct language. Writing skills will 
not come automatically, but must go through a lot of practice and practice regularly and discipline. Likewise in communication activities, sentences play a very important role because when someone conveys and receives information, notifies or asks something, the means used are sentences. In addition, according to Barkaoui (2017: 39) expressing an opinion regarding writing is a finally, sociocultural research sees writing development as the learning of the genres, values, and practices of the target community. Writing is also one of the aspects required in learning Indonesian. Writing can transfer thoughts or feelings into the form of language symbols. Writing is used to communicate indirectly, not face to face with other people. Writing activities will help students to develop their skills and ideas, especially in writing explanatory texts. In writing, especially writing text that is scientific, of course, must use effective sentences. Effective sentences are sentences written in accordance with applicable grammar rules so that readers and listeners can easily understand them.

It is the exposure of the steps or stages that confirms the importance of using or writing good and effective sentences. Because sentences are one of the factors that support an effective text or essay for readers because sentences bring readers to become acquainted with the content of a writing. A good and effective sentence will make it easier for the reader to describe or explain the contents of the writing so that it can increase the reader's knowledge. Effective sentence writing skills are generated in the form of various writings including writing procedural texts. Sentences coupled with other sentences will form a paragraph. A collection of various paragraphs will form a text. (Wijayanti, Zulaeha, \& Rustono, 2015) explanatory text is a type of text that describes the relationship between logic and events. Explanation texts usually contain research reports that are submitted to the public. Explanatory text is not only used to explain research results.

The meaning of text in the 2013 Curriculum is different from the meaning of the text so far. So far, texts have been interpreted as written discourse. In the 2013 Curriculum, text is not interpreted as a form of written language. Text is interpreted as a language unit that expresses meaning contextually. Explanatory text is a new type of text that is available in the 2013 curriculum. Explanatory text is arranged in a structure that includes general statements, a series of explanations, and interpretations (optional). Learning basic competencies about explanatory text is suitable to be integrated with critical reading learning and can be studied and analyzed with a critical thinking perspective (Bambang Eko Hari Cahyono, Lulus Irawati and Devit Tri Candrawati; 2019).

Explanatory text can also be used to explain simple events that occur around humans. The effective sentences referred to here are sentences that are good and true. True according to the prevailing rules or grammar, and good according to the situation so that it is easily understood by the listener or reader. In line with the opinion of Sari \& Anindyaarini (2015), stating that the explanatory text has been previously described, it can be concluded that writing explanatory text is a series of productive and expressive activities carried out by someone. This activity contains the expression of ideas conveyed in written language in the form of explanatory text which has a thinking structure, title, general statement, a series of explanations and interpretations. The use of effective sentences in explanatory text can prevent misunderstandings of interpretation. In line with research conducted by Itaristanti (2015), which he wrote, a sentence coupled with another sentence will form a paragraph. A collection of various paragraphs will form a text. In its preparation, sometimes text writers pay less attention to the characteristics of an effective sentence. Explanatory text is studied by high school students according to the 2013 curriculum. The deficiencies in writing sentences are seen in the accuracy in the use of conjunctions and the principle of saving words, so that the ineffectiveness of the sentences does not pay attention to the savings in words, there are some sentences that have no subject, the use of conjunctions that is not appropriate sentence.

Apart from effective sentence mastery, learning motivation is a variable in determining whether students' writing activities can experience better changes by learning. According to Amna Emda's opinion (2017), according to the results of her research, learning motivation is a major activity in the educational process in business schools that are carried out consciously to change attitudes and behavior. Motivation has an important position in achieving predetermined learning goals. Generating motivation in students does not only involve the students themselves, but the role of the teacher is very important. Learning motivation can be classified into two, namely intrinsic motivation (a state of state that comes from within the student himself which can encourage him to take learning actions) and extrinsic motivation (a condition that comes from outside the individual student that encourages him to carry out learning activities). Whether there is motivation to learn greatly affects student learning success. Learning success will be achieved if there is a willingness and encouragement to learn. 
Wina Sanjaya (2010: 249) says that the learning process of motivation is a very important dynamic aspect. It often happens that students who are underachieving are not caused by their lack of ability, but because there is no motivation to learn so that they do not try to direct all their abilities. In the traditional learning process that uses an expository approach, the teacher sometimes forgets the motivational elements. The teacher seems to force the students to accept the material he delivers. This situation is not beneficial because students cannot learn optimally which of course the achievement of learning outcomes is also not optimal. The modern view of the learning process places motivation as an important aspect in generating student learning motivation.

Motivation is an important determinant in the learning process. Motivation in learning plays a role in fostering passion, feeling happy and enthusiastic about learning (Emria Fitri, Nevriyani, Ifdil: 2016). In addition, the opinion of Iik Faiqotul Ulya, Riana Irawati, Maulana (2016) that low student motivation can have an impact on student learning processes and outcomes that do not improve properly, even greatly decrease. Motivation has an important role in student learning success. Students who are highly motivated are more likely to succeed than students who are not motivated at all. In addition, the opinion of Titian, Kunjana, Yuliana, Pranowod (2020) revealed that learning motivation in the learning process is very important, because motivation is the main mover that appears in students naturally as an increase in interest in learning activities. With the existence of learning motivation, it makes it easier for students to achieve maximum learning quality

\section{Methods}

This type of research is a quantitative study using a correlational method. Arikunto (2010: 10) who says that in quantitative research, measurement results are required to use numbers, starting from data collection, interpretation of data, and in the appearance of the results. The method used in this research is the correlational method. The correlational method used by researchers is different from other researchers, the method used by Dinari Oktaria, Andayani, Kundharu Saddhono (2017), the research method used in this study is a survey method with correlational techniques. Arikunto (2010: 313) the correlational method is a statistical tool that can be used to compare the measurement results of two different variables in order to determine the level of the relationship between these variables, so the correlational method aims to find whether there is a relationship. Arikunto (2010: 16I) The correlational method is a method designed to examine the relationship between variables, namely effective sentence mastery as a variable (XI), interpersonal intelligence as a variable (X2) and persuasion text writing skills as a variable (Y) (Fahmi Hafidatul Hidayati, Suprani and Tatu Hilaliyah: 2019). In this method, find out whether a study has a relationship and the level of the relationship between two or more variables without any effort to influence these variables so that there is no data manipulation.

This is in accordance with the opinion of Studies (2018) "Two symptoms are said to have a correlation, if each change in one symptom is always followed by a change in another symptom, where each of these changes occurs proportionally". The conclusion is that correlation is a form of data analysis by analyzing two variables that have a reciprocal relationship that occurs professionally. Variables are objects that become a point of attention in a study. This study has two variables, namely the independent variable and the dependent variable. The data obtained in this study are in the form of measurement results of the three variables studied and collected through questionnaires and written tests. The first independent variable, namely learning motivation is researched and collected through a questionnaire, while the second independent variable, namely effective sentence mastery which is collected and researched by objective tests, and the dependent variable, namely the writing skills of explanatory text are researched and collected through written tests.

The research instrument is a tool used to collect data in order to solve the problem under study. This is in accordance with the opinion of Sugiyono (2016: 222) which states that research instruments are tools used to obtain or collect data in order to solve research problems or achieve research objectives. Quality of research instruments with regard to the validity and reliability of the instruments and the quality of data collection with regard to the accuracy of the methods used to collect data. Data collection tools used in this study were questionnaires and skills tests (performance tests). Data collection using questionnaires was conducted to collect learning motivation data. The following describes further instrument development.

\section{Learning Motivation Questionnaire}


The learning motivation questionnaire was developed by knowing and measuring how a person's attitude towards writing was used, a questionnaire was developed based on the indicators previously described. Indicators will be used as benchmarks for making instrument items in the form of questions or statements that need to be answered by respondents. The preparation of the instrument questionnaire sheet is carried out by the following steps. First, examining theories related to learning motivation. Second, determine the indicators according to the theory of learning motivation. Third, create a grid based on the indicators derived from the theory used. Fourth, compiling statement items according to indicators. Fifth, conduct a rational analysis to see the suitability of the indicator questionnaire items and the accuracy of preparing the questionnaire items in terms of being measured. Sixth, consult with the guidance and validators to obtain the validity of the items according to the construct.

Measurement of learning motivation can be measured using a Likert scale questionnaire. Sugiyono (2016: I36) explains that the Likert scale is used to measure the attitudes, opinions and perceptions of a person or group of people about social phenomena. With a Likert scale, the variables to be measured are translated into variable indicators. Then the indicator is used as a starting point for arranging items which can be a statement or a question. The answer to each instrument item tested using a Likert scale has a gradient from positive to negative. The questionnaire used to measure students' learning motivation in writing expansive text is presented in the form of a statement. Statement items contain statements that are positive and negative. These positive and negative statements are made to determine the level of respondent understanding of the contents of the statement. Respondents only answer by choosing one of the five answer choices. The five alternative answers are Always (SL), Often (SR), Sometimes (KD), Rarely (JR) and never (TP). Each of these answers is associated with a number or value $\mathrm{SL}=5, \mathrm{SR}=4, \mathrm{KD}=3, \mathrm{JR}=2$, and $\mathrm{TP}=\mathrm{I}$ for positive statements, while for negative statements, $\mathrm{SL}=$ $\mathrm{I}, \mathrm{SR}=2, \mathrm{KD}=3, \mathrm{JR}=4, \mathrm{TP}=5$.

\section{Objective Tests}

The objective test is used to measure the level of effective sentence mastery of high school students. Students answer questions with choices A, B, C, D and E. The instrument is arranged based on predetermined indicators of assessment of effective sentence mastery, namely structural equivalence, alignment of forms, assertiveness of meaning, savings of words, accuracy of words, accuracy of reasoning, coherence of ideas, and logic. language. Before being used for research, objective tests are trialled first. Instrument testing is carried out in a class that is outside the sample.

The objective test, the research instrument was tested first in the population outside the study sample. The trial was conducted to determine the validity of the items and the reliability of the tests so that the data collected could be accounted for. The objective test in the form of multiple choices must first be tested against other students outside the predetermined sample. The number of research samples taken during the trial was 50 people. Based on the scores obtained in the trial test, the validity, reliability and difficulty level of the item questions were analyzed. Item validity is to determine whether a test is valid or not. Meanwhile, the reliability of the test is used to determine the level of confidence, accuracy, or reliability of the test. This is intended to determine the appropriateness of the instruments used, so that the validity of the data collected can be accounted for. The difficulty level of the item is used to determine the ability and ability of students to answer the test. The level of difficulty is also used to evaluate the learning outcomes of students.

The data collection steps in this study are as follows. First, a questionnaire is given to students, then students fill out each statement on the questionnaire sheet by affixing a checklist. Second, students are given an objective test to measure effective sentence mastery by filling in the answer sheets provided by putting a cross (X) on the answer choices that are considered the most correct. Third, students are given a written test to measure the ability to write explanatory text. Fourth, all the collected answer sheets are checked according to predetermined aspects and criteria. After the data is collected, data analysis is then carried out. 
In this study, before the data were analyzed, first the analysis requirements were tested, namely the normality test using the Liliefors test, the homogeneity test using the F-test, and the linearity test. The steps in analyzing data in this study are as follows. First, research data in the form of scores is converted into values using a formula. Second, the values obtained are classified in the table of mastery level determining the benchmark by calculating the percentage for a scale of ten. Third, data description for each variable is done by determining the standard deviation and compiling the data in the form of a frequency distribution table.

The research data were analyzed using simple and multiple correlation tests. The correlation test is intended to test the research hypothesis. The steps to test the hypothesis of this study are (I) the first and second hypotheses are tested by correlating the independent variables of effective sentence mastery (XI) and learning motivation (X2) with the dependent variable writing explanatory text $(\mathrm{Y})$ using the Pearson correlation test. Product Moment (PPM); (2) the third hypothesis is tested by correlating the effective sentence mastery variable (XI) and learning motivation (X2) together with the explanatory text writing variable $(\mathrm{Y})$ using the multiple correlation test formula. After doing the correlation test, it is followed by multiple regression test using correlation and regression techniques.

\section{Research Results And Discussion}

\section{Research Result \\ Effective Sentence Mastery}

The results of data processing on the effective sentence mastery variable consisting of 40 questions were given to 50 students with the lowest score of 16 and the highest score of 29. The calculation results of the effective sentence mastery of the data were obtained an average of 22.96 , media 22 , mode 22 , and standard deviation 3.09. the calculation shows that the mean, median and mode of the data are not much different. This identifies that the variable frequency distribution of students' effective sentence mastery tends to be normally distributed. To obtain an overview of effective sentence mastery, the interval class is determined by: (I) range, the difference between the upper class and the lower class is $29-16=13$. (2) many class intervals, $I+3,3 \log n=I+3,3 \log 50=I+3,3$ $(I, 6989)=6,606$ rounded to 7 . (3) class width, range divided by many classes i.e. I3/7 $=1.852$ rounded to 2 .

Table I. Frequency Distribution of Effective Sentence Mastery

\begin{tabular}{cccc}
\hline No & $\begin{array}{c}\text { Kelas } \\
\text { Interval }\end{array}$ & $\begin{array}{c}\text { Frekuensi } \\
\text { Absolute }\end{array}$ & $\begin{array}{c}\text { Frekuensi } \\
\text { Relatif } \\
\%\end{array}$ \\
\hline I & I6-17 & 2 & 4 \\
2 & 18-19 & 3 & 6 \\
3 & $20-21$ & I & 22 \\
4 & $22-23$ & I & 28 \\
5 & $24-25$ & 8 & 16 \\
6 & $26-27$ & 8 & 16 \\
7 & $28-29$ & 4 & 8 \\
\hline
\end{tabular}

In the table above the frequency value of $28 \%$ of the total respondents obtained the average group score of effective sentence mastery. As is known, the average score is 22,960. respondents who obtained scores below the average interval class were $32 \%$, while respondents who obtained scores above the average interval class were $40 \%$. In general, in writing, you should pay attention to grammar, vocabulary, and spelling so that the sentences written are understood properly and correctly in writing explanatory text. When writing a sentence, mastery of a 
sentence can effectively show the idea or idea so that the sentence written is in accordance with the sentence structure. correct. In addition, it can pay attention to the choice of words and punctuation so that sentences do not become misinterpreted. The precise choice of words and spelling makes the ideas or thoughts to be conveyed clear, so that it can be seen on the average mastery of students' effective sentences that have been entered in the single frequency table below.

Table 2.Frequency Distribution of Effective Sentence Mastery (XI)

\begin{tabular}{ccccc}
\hline No & X & F & FX & Ket \\
\hline I & 90 & 4 & 360 & BS \\
2 & 80 & I3 & I040 & B \\
3 & 70 & 23 & I6I0 & LDC \\
4 & 60 & 8 & 480 & C \\
5 & 50 & 2 & I00 & BC \\
& & N=50 & & \\
& & & $\begin{array}{c}\sum \mathrm{fFX} \\
=359 \\
0\end{array}$ & \\
& & & 0 &
\end{tabular}

\section{Learning Motivation}

The results of data processing variable learning motivation scores consisting of 35 statements given to 50 students obtained the lowest score of 59 and the highest score of I59. The calculation results of the learning motivation questionnaire, the data obtained an average of I I5.62, median I I8.5, mode I22 and standard deviation of 23.06. The calculation shows that the mean, median, and mode of the data are not much different. This indicates that the frequency distribution of the learning motivation variable tends to be normally distributed. To get an overview of the learning motivation score can be determined by: (I) range, the difference between the upper class and the lower class is $I 59-59=I 00$. (2) many interval classes, $I+3,3 \log n=I+3,3 \log 50=I+3,3(I, 6989)$ $=6,606$ rounded to $7,(3)$ class width, range divided by many classes, namely I00/7 $=14,285$ rounded to 15 . 
Table 3. Frequency Distribution of Learning Motivation Questionnaires

\begin{tabular}{cccc}
\hline No & $\begin{array}{c}\text { Kelas } \\
\text { Interval }\end{array}$ & $\begin{array}{c}\text { Frekuensi } \\
\text { Absolute }\end{array}$ & $\begin{array}{c}\text { Frekuensi } \\
\text { Relatif } \\
\%\end{array}$ \\
\hline I & $59-73$ & 2 & 4 \\
2 & $74-88$ & 6 & I2 \\
3 & $89-103$ & 7 & I4 \\
4 & I04- & I0 & 20 \\
& II8 & & \\
5 & II9- & I4 & 28 \\
& I33 & & \\
6 & I34- & 7 & I4 \\
& I48 & & \\
7 & I49- & 4 & \\
& I63 & & \\
\hline
\end{tabular}

The table above shows that the frequency of $20 \%$ of the respondents obtained the average group score of learning motivation. As is known, the average score is I 15.62. Respondents who obtained scores below the average interval class were $30 \%$, while respondents who obtained scores said to be the average interval class were $50 \%$. In general, it can be seen that student learning motivation tries to increase learning motivation by reading books either by force or without coercion in reading books to increase learning motivation, to increase learning motivation not only by reading books but also discussing with friends about lesson material to be studied. In general, understanding of learning motivation can be grouped into six categories, so from the predetermined standard of learning motivation the average learning motivation has been included in the table below with a single frequency distribution table. 
Table 4.Frequency Distribution of Learning Motivation (X2)

\begin{tabular}{ccccc}
\hline No & X & F & FX & Ket \\
\hline I & 90 & 8 & 720 & BS \\
2 & 80 & 9 & 720 & B \\
3 & 70 & I7 & II 90 & LDC \\
4 & 60 & 8 & 480 & C \\
5 & 50 & 7 & 350 & HC \\
6 & 40 & I & 40 & K \\
\hline & & N=50 & & \\
& & & 0 &
\end{tabular}

\section{Writting Explanatory Text}

The results of variable data processing of writing explanatory text for students obtained the lowest score of 70 and the highest score of 90 . The calculation results of the effective sentence mastery of data obtained an average of 79.7 , median 80 , mode 75 , and standard deviation of 6.34 . the calculation shows that the mean, median and mode of the data are not much different. This identifies that the variable frequency distribution of students' effective sentence mastery tends to be normally distributed. To obtain an overview of effective sentence mastery, the interval class is determined by: ( $\mathrm{I}$ ) range, the difference between the upper class and the lower class is 90-70 =20. (2) many class intervals, I $+3,3 \log n=I+3,3 \log 50=I+3,3(I, 6989)=6,606$ rounded to 7 . (3) class width, range divided by many classes i.e. $20 / 7=2.857$ rounded to 3 .

\section{Table 5. Frequency Distribution of Explanatory Text Writing}

\begin{tabular}{cccc}
\hline No & $\begin{array}{c}\text { Kelas } \\
\text { Interval }\end{array}$ & $\begin{array}{c}\text { Frekuensi } \\
\text { Absolute }\end{array}$ & $\begin{array}{c}\text { Frekuensi } \\
\text { Relatif } \\
\%\end{array}$ \\
\hline I & $70-72$ & 6 & $\mathrm{I} 2$ \\
2 & $73-75$ & I5 & 30 \\
3 & $79-81$ & I3 & 26 \\
4 & $85-87$ & 8 & 16 \\
5 & $88-90$ & 8 & 16 \\
\hline
\end{tabular}

In the table above, it can be seen that the frequency of $26 \%$ of the respondents obtained an average group score of writing explanatory text. As is known, the average score was 79.7. Respondents who obtained scores below the average interval class were $26 \%$, while respondents who obtained scores said to be the average interval class were $32 \%$. In general, students' explanatory text writing skills can be grouped into 3 categories, so from the predetermined standard the average writing of expansive text has been entered in the table below with a single frequency distribution table. 
Table 6. Distribution of the Frequency of Writing Explanatory Text

\begin{tabular}{ccccc}
\hline No & X & F & FX & Ket \\
\hline $\mathrm{I}$ & 90 & I6 & I440 & BS \\
2 & 80 & 28 & 2240 & B \\
3 & 70 & 6 & 420 & LDC \\
\hline & & $\mathrm{N}=50$ & $\sum \mathrm{fFX}=4 \mathrm{I00}$ &
\end{tabular}

\section{Relationship of Effective Sentence Mastery on Explanatory Text Writing Skills}

The first hypothesis proposed in this study is "there is a significant relationship between effective sentence mastery and explanatory text writing skills". To see the calculation results, the following hypothesis testing is carried out: $H_{0}$ : there is no relationship between effective sentence mastery and writing skills of explanatory text

$\mathrm{H}_{\mathrm{I}}$ : there is a relationship between effective sentence mastery and explanatory text writing skills.

By making a decision if $\mathrm{H}_{\mathrm{o}}=$ if the value is significant $>$ alpha significance value $(0.05) . \mathrm{H}_{\mathrm{I}}=$ if the significant value $<$ alpha significance value $(0.05)$. Correlation analysis to determine the relationship of effective sentence mastery to writing explanatory text using Pearson Product Moment of rxy 0.352 with t-count of 4.327. Thus, there is an effective sentence mastery relationship to writing explanatory text. This means that the higher the students' mastery of effective sentences, the better or higher the skills in writing explanatory text. With a determination coefficient of 0.274 , it means that the relationship between the effective sentence mastery variable on writing explanatory text is $30.5 \%$.

From the results of a simple regression analysis of the research data pair between the independent variable (XI) and the dependent variable (Y), the regression direction coefficient (b) is 1.045 and the constant (a) is 55, 102. Thus, the form of the relationship between the two variables can be stated. with the regression equation $\dot{Y}=$ $55.102+1.045$ XI. The results of data processing using regression equations show that effective sentence mastery is improved by just one score, so the tendency of explanatory text writing skills increases by 1.045 at a constant of 55.I02. Overall, it can be concluded that effective sentence mastery has a significant relationship with explanatory text writing skills by $30.5 \%$. Therefore, the better the students' knowledge of effective sentences, the better the sis will be in writing explanatory text. To determine the degree of linearity and the significance of the regression equation, it is necessary to test-F. The results of Uji_F can be seen in the following table.

Table 7. Analysis of Variance (ANOVA) Test of Significance and Linearity of Simple Regression

\begin{tabular}{cccccc}
\hline $\begin{array}{c}\text { Sumber } \\
\text { Variansi }\end{array}$ & $\mathrm{dk}$ & $\mathrm{JK}$ & $\mathrm{RJK}$ & $\begin{array}{c}\mathrm{F}_{\text {hitu }} \\
\mathrm{ng}\end{array}$ & $\begin{array}{c}\mathrm{F}_{\text {tabel }} \\
@=0,05\end{array}$ \\
\hline Total & 50 & $\begin{array}{c}3 \mathrm{I} 875 \\
0\end{array}$ & & & \\
\hline $\begin{array}{c}\text { Regresi } \\
\text { (a) }\end{array}$ & $\mathrm{I}$ & $\begin{array}{c}3 \mathrm{I} 680 \\
8\end{array}$ & & & \\
Regresi & $\mathrm{I}$ & $53 \mathrm{I}, 57$ & $53 \mathrm{I}$, & $\mathrm{I} 8$, & 4.080 \\
(b/a) & & $\mathrm{I}$ & $57 \mathrm{I}$ & $\mathrm{I} 37$ & \\
Sisa & 48 & $\mathrm{I} 409,4$ & 29,3 & & \\
& & 29 & 63 & & \\
& & & & & \\
\hline
\end{tabular}




\section{The Relationship between Learning Motivation and Explanatory Text Writing Skills}

The second hypothesis proposed in this study "there is a significant relationship between learning motivation and explanatory text writing skills". To see the calculation results, the following hypothesis testing is carried

out: $\mathrm{H}_{\mathrm{o}}$ : there is no relationship between learning motivation and explanatory text writing skills $\mathrm{H}_{\mathrm{I}}$ : there is a relationship between learning motivation and explanatory text writing skills

By making a decision if $\mathrm{H}_{\mathrm{o}}=$ if the value is significant $>$ alpha significance value $(0.05) . \mathrm{H}_{\mathrm{I}}=$ if the significant value $<$ alpha significance value (0.05). Based on the results of the correlation to the pair of data between learning motivation and explanatory text writing skills using Pearson Product Moment of rxy 0.476 with a t-count of 3.946. Thus, there is a relationship between learning motivation and writing explanatory text, which means that the higher the learning motivation possessed by students, the higher the writing skills possessed by students. This can be seen by the coefficient of determination of 0.248 , which means that the relationship between these two variables is $24.8 \%$.

From the results of simple regression analysis, there is a learning motivation variable (X2) and writing explanatory text $(\mathrm{Y})$, the regression direction coefficient $(\mathrm{b})$ is 0.136 and the constant $(\mathrm{a})$ is 63.478 . Thus, the form of the relationship between the two variables can be expressed by the regression equation $\dot{Y}=63.478+$ 0.I36 X2. Overall, it can be concluded that learning motivation has a significant relationship with the writing skills of explanatory text by $24.8 \%$. Therefore, if the learning motivation possessed by students is high in improving learning, the explanatory text writing skills will also be high. To determine the degree of linearity and the significance of the regression equation, it is necessary to test-F. The results of Uji_F can be seen in the following table.

Table 8. Analysis of Variance (ANOVA) Test of Significance and Linearity of Simple Regression

\begin{tabular}{|c|c|c|c|c|c|}
\hline $\begin{array}{c}\text { Sumbe } \\
r \\
\text { Varian } \\
\text { si }\end{array}$ & $\mathrm{dk}$ & JK & RJK & $\begin{array}{c}\text { F }_{\text {hitu }} \\
\text { ng }\end{array}$ & $\begin{array}{l}\mathrm{F}_{\text {tabel }} \\
@=0,05\end{array}$ \\
\hline Total & 50 & $\begin{array}{c}31875 \\
0\end{array}$ & & & \\
\hline $\begin{array}{l}\text { Regresi } \\
\text { (a) }\end{array}$ & I & $\begin{array}{c}31680 \\
8\end{array}$ & & & \\
\hline $\begin{array}{l}\text { Regresi } \\
(\mathrm{b} / \mathrm{a})\end{array}$ & I & $\begin{array}{c}48 \mathrm{I}, 3 \\
10\end{array}$ & $\begin{array}{l}48 \mathrm{I} \\
310\end{array}$ & $\begin{array}{l}\text { I5, } \\
816\end{array}$ & $\begin{array}{c}4.08 \\
0\end{array}$ \\
\hline Sisa & 48 & $\begin{array}{c}160,6 \\
5\end{array}$ & $\begin{array}{c}30,4 \\
3 \mathrm{I}\end{array}$ & & \\
\hline
\end{tabular}

\section{Correlation of Effective Sentence Mastery and Learning Motivation on Explanatory Text Writing Skills}

The third hypothesis proposed in this study "there is a significant relationship between learning motivation and explanatory text writing skills". To see the calculation results, the following hypothesis testing is carried out:

$H_{0}$ : there is no relationship between effective sentence mastery and learning motivation on explanatory text writing skills

$\mathrm{H}_{\mathrm{I}}$ : there is a relationship between effective sentence mastery and learning motivation on explanatory text writing skills

By making a decision if $H_{\circ}=$ if the value is significant $>$ alpha significance value $(0.05) . H_{\mathrm{I}}=$ if the significant value $<$ alpha significance value $(0.05)$. Based on the results of multiple regressions on the explanatory 
text writing variable $(\mathrm{Y})$, the direction coefficient of multiple regression $(\mathrm{b})$ is 0.094 for effective sentence mastery (XI) and 0.79I for learning motivation (X2) and a constant (a) of 50.547. Thus, the form of the correlation between the three variables can be expressed by the multiple regression equation $\dot{Y}=50.547+0.094 \mathrm{XI}+0.79 \mathrm{I}$ $\mathrm{X} 2$. To find out the degree of linearity and significance of the multiple regression equation, it can be seen in the following table.

\section{Table 9. Results of Multiple Regression Variance Analysis}

\begin{tabular}{|c|c|c|c|c|c|}
\hline \multicolumn{6}{|c|}{ ANALISIS REGRESI GANDA } \\
\hline \multicolumn{2}{|c|}{ Multipplee R. } & \multicolumn{4}{|l|}{$\begin{array}{c}0,6 \mathrm{I} \\
3\end{array}$} \\
\hline R.Square & & $\begin{array}{c}0,37 \\
5\end{array}$ & & & \\
\hline \multicolumn{6}{|c|}{ ANALISIS VARIANS } \\
\hline $\begin{array}{l}\text { Sumber } \\
\text { Varians }\end{array}$ & $\mathrm{dk}$ & $\mathrm{JK}$ & RJK & $F_{\text {hitung }}$ & $\begin{array}{c}\mathrm{F}_{\text {tabel }} \\
@=0 \\
, 05\end{array}$ \\
\hline Regresi & 2 & 1942 & $\begin{array}{l}364, \\
327\end{array}$ & $\begin{array}{c}\mathrm{I} 4, \mathrm{I} \\
\mathrm{I} 3\end{array}$ & 3,18 \\
\hline Sisa & 48 & $\begin{array}{l}\mathrm{I} 2 \mathrm{I} 3 \\
, 346\end{array}$ & $\begin{array}{c}25,8 \\
16\end{array}$ & & \\
\hline Total & 50 & $\begin{array}{l}798 \\
765\end{array}$ & & & \\
\hline
\end{tabular}

\section{Discussion}

The partial correlation coefficient $(\mathrm{R})$ is 0.613 in the direction of positive correlation $(+)$. meaning that the better the value of effective sentence mastery and learning motivation, the better and the skills of writing explanatory texts increased. The correlation has a significant value between effective sentence mastery and learning motivation on secret text writing skills at the coefficient of determination $\mathrm{R} 2=0.375$, effective sentence mastery and learning motivation affect explanatory text writing skills by $37.5 \%$. In accordance with this explanation, effective sentence mastery and learning motivation have an influence on explanatory text writing skills. In accordance with the opinion of Uno (2012: 23) states that the essence of learning motivation is internal and external encouragement for students who are learning to make behavioral changes, in general by using several indicators or supporting elements. Furthermore, Suhana and Hanafiah (2012: 26) add that learning motivation is a power (power motivation), driving force, or a means of building a strong willingness and desire in students to learn actively, creatively, effectively, innovatively, and fun in the context of behavior change, both in cognitive, affective, and psychomotor aspects. Meanwhile, Winkel (1996:27) argues that motivation is a driving force that has become active, motivation becomes active at certain times. Meeting these needs a person will continue to be motivated to do something until he achieves his goals. The urge that arises from within a person to do something in order to fulfill a need is called motivation.

An interaction occurs when the effect of one factor depends on other factors in influencing something (Irianto, 2004: 225). This means that effective sentence mastery with student motivation depends on one another in influencing explanatory text writing skills. Based on the double correlation of the third hypothesis, it can be seen that there is a correlation between effective sentence mastery and learning motivation on explanatory text writing skills. As stated earlier, correlation is the effect of the interaction and treatment of effective sentence mastery and learning motivation. Providing materials regarding effective sentence mastery in learning to write explanatory text aims to make it easy for students to plan what will be written into a text in the form of explanation. Effective 
sentences are an alternative in providing learning materials that can be done in the learning process of writing explanatory text.

\section{Conclusion}

Based on data analysis and discussion, it can be concluded that sentence mastery effectively affects learning outcomes to write expansive text. First, the test results of explanatory text writing skills taught creatively can make it easier to understand concepts and memorize the information with a learning infrastructure. Educators as facilitators should create creative and innovative learning in the learning process so that they can help students well. Because the learning process is focused on students who are learning, not educators who teach. Second, students 'learning motivation, whether high or low, both have an effect on the learning outcomes of students' expalanation text writing skills when taught. Learning outcomes will be more optimal if there is motivation. Motivation to learn can function as a driving force, direction, and at the same time driving one's behavior to achieve goals.

\section{Acknowledgments}

On this occasion, the author also thanks all those who have helped and supported the research so that it can be carried out according to the plan that was designed in advance.

\section{References}

Amna Emda .2017. Kedudukan Motivasi Belajar Siswa Dalam Pembelajaran. Lantanida Journal, Vol. 5 No. 2. hal, 93-196.

Arikunto, Suharsimi. 2010. Prosedur Penelitian Suatu Pendekatan Praktik. Jakarta: Rineka Cipta.

Bambang Eko Hari Cahyono, Lulus Irawati dan Devit Tri Candrawati .2019. Implementasi Model Pembelajaran Rekreasi-Prokreasi Dalam Membaca Kritis Teks Eksplanasi Di SMK. Jurnal Indonesian Languange Education And Literature (ILEaL). Vol. 5, No. I Desember 2019, hal 6I - 73.

Barkaoui, Khaled. 2007. Teaching Writing to Second Language Learners: Insights from Theory and Research. TESL Reporter . 40 (I): hal, 35-48.

Dinari Oktaria, Andayani,Kundharu Saddhono (2017). Penguasaan Kalimat Efektif sebagai Kunci Peningkatan Keterampilan Menulis Eksposisi. Jurnal Metalingua volume I5 nomor 2, hal I65-I77.

Emianna Tumanggor. 2016. Hubungan Penguasaan Kalimat Efektif Dengan Kemampuan Menulis Teks Pidato Oleh Siswa Kelas Xi SMA IPA Budi Angung Medan. Jurnal Kultura Edukasi volume 3 nomor I, hal 5257.

Emria Fitri, Nevriyani, Ifdil. 2016. Efektivitas Layanan Informasi Dengan Menggunakan Metode Blended Learning Untuk Meningkatkan Motivasi Belajar. Jurnal Psikologi Pendidikan \& Konseling Volume 2 Nomor 2 Juni 2016. Hal 84-92.

Fahmi Hafidatul Hidayati, Suprani dan Tatu Hilaliyah. (2019). Hubungan Penguasaan Kalimat Efektif Dan Kecerdasan Interpersonal Dengan Keterampilan Menulis Teks Persuasi Siswa Kelas VIII SMP N 26 Kota Tangerang. Jurnal Membaca Bahasa dan Sastra Indonesia. Vol 4 No 2, hal 85-95.

Geaa Titian Berkat, Kunjana Rahardib, Yuliana Setyaningsihc, Pranowod, (2020). Strategi Meningkatkan Motivasi Belajar Mahasiswa Dengan Model Learning Cycle pada Mata Kuliah Sejarah Sastra Indonesia. Jurnal Bahastra volume 40 no 2. hal I6I-I66.

Iik Faiqotul Ulya, Riana Irawati, Maulana. (2016) Peningkatan Kemampuan Koneksi Matematis Dan Motivasi Belajar Siswa Menggunakan Pendekatan Kontekstual. Jurnal Pena Ilmiah vol I no.I, hal I2I-I30.

Irianto, Agus. 2004. Statistik Konsep Dasar dan Aplikasinya. Jakarta: Perdana Media.

Itaristanti. (20I5). Keefektifan Kalimat dalam teks pada buku pelajaran ilmu pengetahuan sosial. Edueksos Volume IV No I, IV(I), I-I4.

Mulyono, Iyo. 20II. Cerdas Bahasa Cerdas Komunikasi. Bahasa Indonesia Baku dan Problematikanya. Bandung:Yrama Widya.

Sanjaya, Wina. (2010). Kurikulum dan pembelajaran, Teori dan praktek Pengembangan Kurikulum KTSP. Jakarta: Kencana.

Sugiyono. 2016. Metode Penelitian Kuantitatif, Kualitatif, Dan R\&D. Bandung: Alfabet 
Suhana, dan Hanafiah. 20I2. Konsep Strategi Pembelajaran. Bandung: Refika Aditama.

Studies, L. (2018). Hubungan Antara Minat Membaca Dengan Keterampilan Menulis Cerita Pendek Siswa Kelas VSD Gugus VII. I(I), 43-5I

Uno, Hamzah B. 20I2. Teori Motivasi dan Pengukurannya. Jakarta: PT. Bumi Aksara

Wijayanti, W., Zulaeha, I., \& Rustono. (2015). Pengembangan Bahan Ajar Interaktif Kompetensi Memproduksi

Teks Prosedur Kompleks Bermuatan Kesantunan Bagi Peserta Didik Kelas X SMA/Ma. Seloka: Jurnal Pendidikan Bahasa Dan Sastra Indonesia, 2 (2), hal, 94-IOI.

Winkel, WS. 1996. Psikologi Pengajaran. Jakarta: Grasindo Sinar Baru.

Sari, A. M., Suwandi, S., \& Anindyaarini, A. (2015). Peningkatan Motivasi Belajar Dan Keterampilan Menulis Teks Eksplanasi Kompleks Melalui Metode Kooperatif Tipe Picture And Picture Pada Siswa SMK. Jurnal Penelitian Bahasa, Sastra Indonesia Dan Pengajarannya, 3(I), hal, I-I9. 